\title{
Olfaction in the fruit-eating bats Artibeus lituratus and Carollia perspicillata: an experimental analysis
}

\author{
LAYS C. PAROLIN ${ }^{1,2,3}$, SANDRA B. MIKICH ${ }^{1}$ and GLEDSON V. BIANCONI ${ }^{4,5}$ \\ ${ }^{1}$ Laboratório de Ecologia, Embrapa Florestas, Estrada da Ribeira, km 111, 83411-000 Colombo, PR, Brasil \\ ${ }^{2}$ Departamento de Zoologia e Botânica, Universidade Estadual Paulista "Júlio de Mesquita \\ Filho”, Rua Cristóvão Colombo, 2265, 15054-000 São José do Rio Preto, SP, Brasil \\ ${ }^{3}$ Escola de Saúde e Biociências, Pontifícia Universidade Católica do Paraná, Rua \\ Imaculada Conceição, 1155, 80215-182 Curitiba, PR, Brasil \\ ${ }^{4}$ Instituto Neotropical: Pesquisa e Conservação, Rua Purus, 33, 82520-750 Curitiba, PR, Brasil \\ ${ }^{5}$ Instituto Federal do Paraná, Campus Pinhais, Rua Humberto de Alencar Castelo Branco, 1575, 83330-200 Pinhais, PR, Brasil
}

Manuscript received on September 30, 2014; accepted for publication on January 19, 2015

\begin{abstract}
Studies suggest that frugivorous bats search and select fruit mainly by olfaction so that they can be attracted by smell alone. The aim of this study was to evaluate, in captivity, the behavioural response (number of foraging attempts) of Artibeus lituratus and Carollia perspicillata offered essential oils extracted from ripe fruit of Ficus insipida (Moraceae) and Piper hispidum (Piperaceae) as well as intact fruit wrapped in gauze to attract bats with reduced visual stimuli. Based on previous reports, we hypothesized that $A$. lituratus would exhibit preference for Ficus fruits/oil while C. perspicillata would prefer Piper fruit/oil. Four arrangements of these attractants were tested in triplicate: $P$. hispidum fruit vs. F. insipida fruit, $P$. hispidum oil vs. F. insipida oil, $P$. hispidum oil vs. F. insipida fruit and $P$. hispidum fruit vs. F. insipida oil. As expected, in all tests, $A$. lituratus showed the highest number of foraging attempts in F. insipida while C. perspicillata in those of $P$. hispidum. Based on the number of foraging attempts both species exhibited a positive response to their favorite fruit genera, though the differences were not always statistically significant. The results confirm the importance of smell in fruit choice by these species.
\end{abstract}

Key words: bats, essential oils, food preference, fruits, smell.

\section{INTRODUCTION}

Phyllostomidae is a family of bats that is known for its richness (approximately 160 species) (Simmons 2005) and also for the importance of its species interactions with the environment (Kunz and Fenton 2003). Olfaction combined with echolocation and

Correspondence to: Gledson Vigiano Bianconi

E-mail: gledson.bianconi@ifpr.edu.br vision, form the set of senses that enable bats to orient in space and search for food (Fleming 1988, Thies et al. 1998). In fact, laboratory experiments have shown that some frugivorous Phyllostomidae (e.g. Artibeus jamaicensis Leach, 1821) posses increased numbers of nasal structures compared to essentially insectivorous species, such as the genus Myotis Kaup, 1829 (Bhatnagar and Kallen 1975). Furthermore, studies have shown that olfaction 
plays an important role in the selection of mature fruits by species such as Artibeus watsoni Thomas, 1901, Carollia perspicillata (Linnaeus, 1758), C. castanea (H. Allen, 1890) and Vampyressa pusilla (Wagner, 1843) (Laska 1990, Mikich et al. 2003, Korine and Kalko 2005).

Following this reasoning, Mikich et al. (2003) and Bianconi et al. (2007) evaluated the attraction of frugivorous phyllostomids to essential oils extracted from ripe chiropterochoric fruit. The results proved so efficient that the same authors proposed a tool for forest restoration based on the attraction of bats to degraded areas and the increase of seed rain (Bianconi et al. 2007, Bianconi et al. 2010). Yet it remains to be proven whether this tool leads to increased seedling recruitment and establishment (Reid and Holl 2013).

Underlying these bat-plant relations, there is an interesting point regarding the preferential consumption of fruits in nature - evidenced when an animal, provided with a choice, uses a particular food source (sensu Chensson 1983). In this approach, the aforementioned phyllostomid genera are classic examples of the Neotropical region. According to many authors (e.g. Fleming 1988, Kalko et al. 1996, Wendeln et al. 2000, Mikich 2002), Artibeus Leach, 1821 shows marked preference for fruits of Ficus L. and Carollia Gray, 1838 for those of Piper L. These findings are generally supported by analyses of faeces and/or direct observations in shelters and/or feeding perches. However, these studies lack the simultaneous assessment of the availability of resources in the area. The number of studies adopting this approach is still small (Fleming 1988, Giannini 1999, Thies and Kalko 2004, Pereira et al. 2010, Mello et al. 2011, Sánchez et al. 2012), which reinforces the need for further studies, especially those that control fruit supply.

So here we tested the response of captive Artibeus lituratus (Olfers, 1818) and Carollia perspicillata offered controlled quantities of olfactory stimuli from two fruit species, Ficus insipida and Piper hispidum, and their respective essential oils. Our hypothesis was that A. lituratus would exhibit preference for Ficus fruit/oil while C. perspicillata would prefer Piper fruit/oil.

\section{MATERIALS AND METHODS}

\section{CAPTURE AND CARE OF BATS}

Bats for the experiments were captured during February 2008 in Atlantic Forest fragments in southern Brazil. Soon after capture, the animals were placed in cotton bags and transported to a facility located in the Scientific Breeding of Wild Animals of the Museu de História Natural Capão da Imbuia, Curitiba - state of Parana, Brazil. The bats were kept in an enclosure with two rooms (2.8 $\mathrm{m} \times 2.5 \mathrm{~m} \times 2.8 \mathrm{~m}$ in height, each) covered with screen. While the bats were not being used in the experiments, they were fed a variety of different fruits. All procedures were carried out according to the international practices for animal use and care under the control of an internal Animal Ethics Committee of the Pontifícia Universidade Católica do Paraná, Brazil (Protocol n. 315).

FRUITS

Ripe fruit of Ficus insipida Willd. (Moraceae) and Piper hispidum Sw. (Piperaceae) used in the experiments were collected at the same locations and periods in which the bats were caught, thus ensuring a prior knowledge of this resource by the animals. The fruits were frozen in $-15^{\circ} \mathrm{C}$ for a maximum of two months until their use in testing or extraction of their essential oils. Ficus is a genus of canopy tree widely distributed in the Neotropics, from Mexico to Paraguay (Banack et al. 2002). Ficus species exhibit a "boom" of maturation, but are generally asynchronous within species (Figueiredo and Sazima 1997, Morrison 1978). Ficus insipida produces fruits (syconia), approximately $24 \mathrm{~mm}$ long by $26 \mathrm{~mm}$ wide, containing 100 to 300 seeds (Bianconi et al. 2007, Mikich and Silva 2001). The genus Piper is 
Pantropical and includes herbs, shrubs and small trees, which are very common pioneers in degraded rural areas (Fleming 1988, Mikich et al. 2003, Thies and Kalko 2004). Their inflorescences are drupes with characteristic chiropterochoric fruit traits i.e., green colour, strong odour and exposure on the outside of leaves (van der Pijl 1957). However, unlike Ficus spp, Piper have sequential ripening fruit within the canopy, offering few mature fruits per night (Dumont 2003), plus a sequential addition of fruit availability between different species of the community (Fleming and Heithaus 1986). The fruits of Piper hispidum are approximately $100 \mathrm{~mm}$ long by $8 \mathrm{~mm}$ wide and have 1000 to 2000 seeds (Mikich and Silva 2001).

\section{ESSENTIAL OIL EXTRACTION}

Essential oils from two species of fruits were extracted by hydrodistillation with a modified Clevenger apparatus (Bianconi et al. 2008). To obtain each ampoule of crude essential oil a total of $300 \mathrm{~g}$ of ripe fruits were boiled for 4 hours (Mikich et al. 2003, Bianconi et al. 2007).

\section{CAPTIVE EXPERIMENTS}

The tests consisted of the simultaneous offering two olfactory attractants, fruit and/or essential oils, hanging by a nylon thread at a height of $50 \mathrm{~cm}$ from the ceiling of the enclosure and separated by $90 \mathrm{~cm}$. For treatments using essential oils, an ampoule was opened at the beginning of testing and dissolved in $2 \mathrm{~mL}$ of diethyl ether, to impregnate two rubber septa (Sigma, $6 \mathrm{~mm}$ long). In the case of fruits, the attractant consisted of one whole fruit wrapped in gauze, so that the bats could not actually see the fruit but could potentially smell it. Accordingly, the rubber septum was also wrapped in gauze when tested against fruit (see arrangements 3 and 4 below) to standardize the stimuli.

Each bat, eight individuals of Artibeus and six of Carollia, was observed across the four different arrangements of paired attractants, each measured three times: 1) $P$. hispidum fruit and F. insipid fruit; 2) $P$. hispidum oil and F. insipida oil; 3) P. hispidum oil and F. insipida fruit and 4) P. hispidum fruit and F. insipida oil.

Irrespective of the arrangement tested, the following steps were followed: i) the stimuli were arranged in the enclosure, ii) one individual was released; iii) foraging attempts were recorded for 10 minutes (see below) right after the individual's first exploration flight; v) the individual was removed from the enclosure; and vi) a new individual was released. The position of the stimuli was switched among the replicates to avoid learning and to randomize sampling.

The observations were done according to the method "all occurrences sampling" (Altmann 1974), by measuring the number of foraging attempts of each individual towards the two different attractants for 10 minutes. The experiments were always conducted at night and viewed from the outside of the enclosure, with the aid of an infrared video camera (SONY DCR-HC28) to reduce disturbances.

\section{DATA ANALYSIS}

A chi-square test was used to examine independence of the number of foraging attempts on each attractant, and the significance level was 0.05.

\section{RESULTS}

After $64 \mathrm{~h}$ of observations, conducted during 37 non-consecutive nights in March, April, July and September 2008, there were 923 bat foraging attempts on the attractants. Artibeus lituratus (eight individuals) totalled 211 attempts while Carollia perspicillata (six individuals) totalled 712 (Table I).

\section{Piper fruit vs. Ficus fruit}

Artibeus lituratus exhibited a low number $(\mathrm{N}=11)$ of foraging attempts on whole fruit so that even though the number of attempts on Ficus were higher 
TABLE I

Number of responses of Artibeus lituratus and Carollia perspicillata in tests with paired attractions offered in captivity. $\mathbf{P h}=$ Piper hispidum and $\mathrm{Fi}=$ Ficus insipida.

\begin{tabular}{ccccc}
\hline \multirow{2}{*}{ Attraction pair } & \multicolumn{4}{c}{ Number of foraging attempts } \\
\cline { 2 - 5 } & \multicolumn{2}{c}{ Artibeus lituratus } & Carollia perspicillata \\
\cline { 2 - 5 } & $\mathrm{Ph}$ & $\mathrm{Fi}$ & $\mathrm{Ph}$ & $\mathrm{Fi}$ \\
\hline 1) P. hispidum fruit vs. F. insipida fruit & 3 & 8 & 116 & 46 \\
2) P. hispidum oil vs. F. insipida oil & 9 & 30 & 87 & 65 \\
3) P. hispidum oil vs. F. insipida fruit & 28 & 59 & 96 & 59 \\
4) P. hispidum fruit vs. F. insipida oil & 30 & 44 & 140 & 103 \\
Total & 70 & 141 & 439 & 273 \\
\hline
\end{tabular}

$(\mathrm{N}=8)$ than on Piper $(\mathrm{N}=3)$, the difference was not statistically significant $\left(\chi_{(1)}^{2}=2.27, \mathrm{P}=0.13\right)$. As for Carollia, the total number of foraging attempts was higher $(\mathrm{N}=162)$ and statistically significant for $P$. hispidum $\left(\chi_{(1)}^{2}=30.24, \mathrm{P}<0.05\right)$.

\section{Piper oil vs. Ficus oil}

Artibeus lituratus showed a significant preference for Ficus essential oil $\left(\chi_{(1)}^{2}=11.3 ; \mathrm{P}<0.05\right)$. Approximately $57 \%$ of Carollia perspicillata attempts occurred on $P$. hispidum, but the difference was not significant $\left(\chi_{(1)}^{2}=3.18, \mathrm{P}=0.07\right)$.

Piper oil vs. Ficus fruit

Artibeus lituratus exhibited a significant preference for Ficus $\left(\chi_{(1)}^{2}=11.04, \mathrm{P}<0.05\right)$ and $C$. perspicillata for Piper $\left(\chi_{(1)}^{2}=8.83 ; \mathrm{P}<0.05\right)$.

\section{Piper fruit vs. Ficus oil}

Even though $A$. lituratus invested $60 \%$ of the foraging attempts on F. insipida oil there was no significant difference $\left(\chi_{(1)}^{2}=2.64, \mathrm{P}=0.10\right)$ between these attractants. Carollia perspicillata on the other hand invested significantly more in the fruit of $P$. hispidum $\left(\chi_{(1)}^{2}=5.63, \mathrm{P}<0.05\right)$.

\section{DISCUSSION}

The majority of Artibeus lituratus foraging attempts suggested a preference for Ficus even though in two out of four arrangements tested the difference was not statistically significant. In this interpretation, the results support the various studies that indicate Ficus spp. as the most common item in Artibeus spp. diet (e.g. Morrison 1978, Handley et al. 1991, Mikich 2002, Giannini and Kalko 2004, Olea-Wagner et al. 2007). Bonaccorso and Gush (1987), in tests with captive Artibeus spp. [Artibeus phaeotis (Miller, 1902), A. toltecus (Saussure, 1860) and A. jamaicensis Leach, 1821] and fruits of Ficus ovalis (Liebm.) Miq, also obtained positive attraction responses to species such as Piper amalago L. and Muntingia calabura L. Morrison (1978) noted that on Barro Colorado Island A. jamaicensis continued to feed on Ficus trees even when other fruits were abundant. The same was observed in this study for A. lituratus which chose Ficus fruits even with the increased supply of Piper (septum with essential oil extracted from approximately $300 \mathrm{~g}$ of fruit). For Dumont (2003) and S.M.C. Francener (Unpublished data), the preference for this Moraceae is related to its high fibre content and low nitrogen and lipid concentrations. To compensate for the low nutrient content, bats feed on large quantities of Ficus fruits and supplement their diet with other species (Bonaccorso and Gush 1987, Dumont 2003).

Experiments with $C$. perspicillata showed a high number of foraging attempts on fruit and essential oil of $P$. hispidum, even when the offer 
of Ficus was greater (Piper fruit $x$ Ficus oil tests). This pattern is similar to what is found in the wild, where Piper provides few mature fruits per night when compared with the Moraceae genus (Dumont 2003). The relationship of this phyllostomid bat with Piperaceae is well documented (e.g. Fleming 1988, Charles-Dominique 1991, Sánchez et al. 2012), with studies suggesting co-evolution between these groups (Thies and Kalko 2004). Bonaccorso and Gush (1987) reported for captive C. perspicillata and C. subrufa (Hahn, 1905), a marked preference for fruits with a high nutritional value, in the case when Piper amalago L. was offered simultaneously with Ficus ovalis fruits. According to authors, the strategy of these bats is to feed on fruits which are rich in protein and low in fibre (Herbst 1986, Bonaccorso and Gush 1987, Fleming 1988), a condition potentially found in Piperaceae (Fleming 1988, Thies and Kalko 2004).

Tests with essential oils showed 191 responses by both bat species, which may indicate that these bats are guided only by the odor to select the preferred ripe fruits. From a more conservative approach, our results also validate studies that indicate olfaction as one of the main sense used by fruit bats for obtaining food (Laska 1990, Thies et al. 1998, Mikich et al. 2003). Additionally, our findings reinforce the hypothesis proposed by Laska (1990), which associates the feeding specificity of bats to olfaction. Similarly, Thies et al. (1998) evaluated the attraction of Carollia spp. (C. perspicillata and C. castanea) to variations in texture, shape, maturity status, position and odor of Piper fruits (P. aequale Vahl., P. dilatatum Rich., $P$. grande Vahl., $P$. marginatum Jacq). Of all the treatments used, the bat species only exhibited a positive response to stimuli containing odor of ripe fruit.

In forest tests conducted by Mikich et al. (2003), C. perspicillata responded strongly to $P$. gaudichaudianum oil even when there was an abundance of fruit availability of this and other Piper species available in the environment. Bianconi et al. (2007), in turn, described the efficacy of essential oils in attracting fruit bats in open areas. Different from that observed by Mikich et al. (2003), oil of $P$. gaudichaudianum mostly attracted $A$. lituratus. In this case, the authors suggest that in areas without resources, as in the case of open pastures and crops, bats can be attracted to odors of other fruits in addition to their preferred choice. It is possible that this attraction is in some way related to similarities in the composition of the essential oils consumed between species and genera.

The experiments in this study demonstrated that Artibeus lituratus responded more frequently to Ficus insipida whereas $C$. perspicillata responded more to Piper hispidum. The number of foraging attempts of both species shows preference for their favorite fruit genera. Moreover, these animals responded positively to odorous stimuli, reinforcing the importance of olfaction in their foraging activity. In this sense, indications were also obtained that these bats may be guided only by odor to select and pick ripe fruit.

\section{RESUMO}

Estudos sugerem que morcegos frugívoros buscam e selecionam o fruto utilizando-se principalmente do olfato, podendo ser atraídos apenas pelo cheiro. $\mathrm{O}$ objetivo deste estudo foi avaliar, em cativeiro, a resposta comportamental (número de tentativas de forrageamento) de Artibeus lituratus e Carollia perspicillata diante da oferta de óleos essenciais extraídos de frutos maduros de Ficus insipida (Moraceae) e Piper hispidum (Piperaceae), bem como de frutos intactos envoltos em gaze para atrair morcegos com estímulo visual reduzido. Baseados em estudos anteriores, nós hipotetizamos que A. lituratus iria preferir frutos/óleo de Ficus enquanto C. perspicillata iria preferir frutos/óleo de Piper. Quatro arranjos desses atrativos foram testados, em triplicatas: fruto de $P$. hispidum vs. fruto de $F$. insipida, óleo de $P$. hispidum vs. óleo de F. insipida, óleo de P. hispidum vs. fruto de F. insipida, e fruto de P. hispidum vs. óleo de F. insipida. Como esperado, em todos os testes, $A$. 
lituratus apresentou o maior número de tentativas de forrageamento em $F$. insipida, enquanto $C$. perspicillata em $P$. hispidum. Com base no número de tentativas de forrageamento, ambas as espécies exibiram uma resposta positiva aos seus gêneros de frutos preferidos, ainda que as diferenças não tenham sido estatisticamente significativas sempre. Os resultados confirmam a importância do olfato na escolha de frutos por essas espécies.

Palavras-chave: morcegos, óleos essenciais, preferência alimentar, frutos, olfato.

\section{REFERENCES}

ALTMANN J. 1974. Observational study of behavior: sampling methods. Behav 49: 227-266.

BANACK SA, HORN MH AND GAWLICKA A. 2002. Disperse vs. establishment-limited distribution of a riparian fig tree (Ficus insipida) in a Costa Rican tropical rain Forest. Biotropica 34: 232-243.

BHATNAGAR KP AND KALLEN FC. 1975. Quantitative observations on the nasal epithelia and olfactory innervation in bats. Acta Anat 91: 272-282.

BIANCONI GV, MiKich SB, MAIA BHLNS, TEIXEIRA SD AND MARQUES FA. 2008. A ecologia química da interação morcego-planta: proposta de uma nova ferramenta para restauração florestal e estudos de auto-ecologia. In: Pacheco C et al. (Eds), Morcegos do Brasil: Ecologia, Biologia e Conservação, Editora Armazém Digital, Porto Alegre, p. 369-374.

BIANCONI GV, MIKICH SB, TEIXEIRA SD AND MAIA BHLNS. 2007. Attraction of fruit-eating bats with essential oils of fruits: a potential tool for forest restoration. Biotropica 39: 136-140.

BIANCONI GV, SUCKOW UMS, CRUZ-NETO AP AND MIKICH SB. 2010. Use of fruit essential oils to assist forest regeneration by bats. Restoration Ecol 20: 211-217.

BONACCORSO FJ AND GUSH TJ. 1987. Feeding behaviour and foraging strategies of captive phyllostomid fruit bats: an experimental study. J Anim Ecol 56: 907-920.

CHARLES-DOMINIQUE P. 1991. Feeding strategy and activity budget of the frugivorous bat Carollia perspicillata (Chiroptera: Phyllostomidae) in French Guiana. J Trop Ecol 7: 243-256.

CHENSSON J. 1983. The estimation and analysis of preference and its relationship to Foraging Models. Ecol 64: 12971304.

DUMONT ER. 2003. Bats and Fruit: An ecomorphological approach. In: Kunz TH and Fenton B (Eds), Bat Ecology, University of Chicago Press, Chicago, p. 398-429.
FigueIREDO RA AND SAZIMA M. 1997. Phenology and pollination ecology of three Brazilian fig species (Moraceae). Bot Acta 110: 73-78.

FLEMING TH. 1988. The short-tailed fruit bat: A study in plantanimal interactions. University Chicago Press, Chicago, $380 \mathrm{p}$.

FLEMING TH AND HEITHAUS ER. 1986. Seasonal foraging behavior of the frugivorous bat Carollia perspicillata. J Mammal 67: 660-671.

GIANNINI NP. 1999. Selection of diets and elevation by sympatric species of Sturnira in an Andean rainforest. J Mammal 80: 1186-1195.

GIANNINI N AND KALKO E. 2004. Trophic structure in a large assemblage of phyllostomid bats in Panama. Oikos 105: 209-220.

HANDLEY JR CO, WILSON DE AND GARDNER AL. 1991. Demography and natural history of the common fruit bat Artibeus jamaicensis on Barro Colorado Island, Panamá. Smithsonian Institution Press, Washington, $173 \mathrm{p}$.

HERBST LH. 1986. The role of Nitrogen from fruit pulp in the nutrition of the frugivorous bat Carollia perspicillata. Biotropica 18: 39-44.

KALKO EKV, HANDLEY JR CO AND HANDLEY D. 1996. Organization, diversity and long-term dynamics of a neotropical bat community. In: Cody ML and Smallwood JA (Eds), Long-term studies of vertebrate communities, Academic Press, New York, p. 503-553.

KORINE C AND KALKO EKV. 2005. Fruit detection and discrimination by small fruit-eating bats (Phyllostomidae): Echolocation call design and olfaction. Behav Ecol Sociobiol 59: 12-23.

KUnZ TH AND Fenton MB. 2003. Bat Ecology. Chicago: The University of Chicago Press, 798 p.

LASKA M. 1990. Olfactory discrimination ability in shorttailed fruit bat, Carollia perspicillata (Chiroptera: Phyllostomidae). J Chem Ecol 16: 3291-3299.

MELLO MAR, MARQUITTI FMD, GUIMARÃES JR PR, KALKO EKV, JORDANO P AND AGUIAR MAM. 2011. The missing part of seed dispersal networks: structure and robustness of bat-fruit interactions. Plos One 6: 1-10.

MIKICH SB. 2002. A dieta dos morcegos frugívoros (Mammalia, Chiroptera, Phyllostomidae) de um pequeno remanescente de Floresta Estacional Semidecidual do sul do Brasil. Rev Bras Zool 19: 239-249.

MIKICH SB, BIANCONI GV, MAIA BHLNS AND TEIXEIRA SD. 2003. Attraction of the fruit-eating bat Carollia perspicillata to Piper gaudichaudianum essential oil. J Chem Ecol 29: 2379-2383.

MIKICH SB AND SILVA SM. 2001. Composição florística e fenologia das espécies zoocóricas de remanescentes de Floresta Estacional Semidecidual no centro-oeste do Paraná, Brasil. Acta Bot Bras 15: 89-113. 
MORRISON DW. 1978. Influence of habitat on the foraging distances of the fruit bat, Artibeus jamaicensis. J Mammal 59: 622-624.

OLEA-WAGNER A, LORENZO C, NARANJO E, ORTIZ D AND LEON-PANIAGUA L. 2007. Diversity of fruits consumed by three species of bats (Chiroptera: Phyllostomidae) in the Lacandona rainforest, Chiapas, Mexico. Rev Mex Biodivers 78: 191-200.

PEREIRA MJR, MARQUes JT AND PALMEIRIM JM. 2010. Ecological responses of frugivorous bats to seasonal fluctuation in fruit availability in Amazonian Forests. Biotropica 42: 680-687.

REID J AND HOLL K. 2013. Arrival $\neq$ Survival. Restoration Ecol 21: 153-155.

SÁNCHEZ MA, GIANNINI NP AND BARQUEZ RM. 2012. Bat frugivory in two subtropical rain forests of Northern Argentina: Testing hypotheses of fruit selection in the Neotropics. Mamm Biol 77: 22-31.
SIMMONS NB. 2005. Order Chiroptera. In: Wilson DE and Reeder DM (Eds), Mammal species of the world: A taxonomic and geographic reference, Johns Hopkins University Press, Baltimore, p. 312-529.

THIES W AND KALKO EKV. 2004. Phenology of neotropical pepper plants (Piperaceae) and their association with their main dispersers, two short-tailed fruit bats, Carollia perspicillata and C. castanea (Phyllostomidae). Oikos 104: 362-376.

Thies W, KALKo EKV AND SCHNitZLER HU. 1998. The roles of echolocation and olfaction in two Neotropical fruit-eating bats, Carollia perspicillata and C. castanea, feeding on Piper. Behav Ecol Sociobiol 42: 397-409.

VAN DER PIJL L. 1957. The dispersal of plants by bats (Chiropterochory). Acta Bot Neerl 6: 291-315.

WENDELN MC, RUNKLE JR AND KALKO EKV. 2000. Nutritional values of 14 fig species and bat feeding preferences in Panama. Biotropica 32: 489-501. 
